\title{
EFEKTIFITAS PELATIHAN KETERAMPILAN HANTARAN BAGI KAUM PEREMPUAN DI DESA CIGUGUR GIRANG KEC. PARONGPONG KAB. BANDUNG BARAT (STUDI KASUS PROGRAM PNPM DESA TAHUN 2015)
}

\author{
${ }^{1)}$ Nandang Rukanda ${ }^{2)}$ Nunu Mahmud Firdaus \\ 1)nandangsae@gmail.com ${ }^{2)}$ mahmudfirdaus@gmail.com \\ ${ }^{1,2)}$ Program Studi Pendidikan Luar Sekkolah, STKIP Siliwangi
}

\begin{abstract}
ABSTRAK
Krisis global yang melanda dunia dengan perekonomian bangsa-bangsa kian terpuruk berakibat kesulitan diseluruh negara yang ada. Krisis dunia ini berdampak pada keprihatinan yang menimpa Bangsa Indonesia, dimana terjadi krisis perekonomian sejak pertengahan tahun 1997 telah berkepanjangan, dengan jumlah pengangguran dan kemiskinan yang semakin banyak. Hal ini dibuktikan dengan tidak terserapnya tenaga kerja pada sektor perekonomian yang ada, dan masih banyak anak-anak yang putus sekolah (dropped out), serta anak-anak usia produktitif yang tidak mampu melanjutkan sekolah ke jenjang yang lebih tinggi. Sebagai salah satu upaya guna menanggulangi krisis ini adalah dengan cara membuat masyarakat terampil melalui pelatihan untuk mempersiapkan mereka masuk ke pasar kerja serta untuk berusaha secara mandiri. Pelatihan-pelatihan sering diselenggarakan bagi masyarakat yang memerlukan bekal pengetahuan, keterampilan, kecakapan hidup, dan sikap untuk mengembangkan diri, mengembangkan profesi, bekerja, usaha mandiri, dan/atau melanjutkan pendidikan kejenjang yang lebih tinggi. Salah satu usaha sektor jasa yang potensial untuk berkembang adalah pembuatan hantaran. Penelitian ini mencoba memaparkan permasalahan berkenaan dengan rumusan deskripsi, yaitu mempertanyakan Bagaimanakah penyelenggaraan pelatihan pembuatan hantaran? Bagaimanakah implementasi yang dilakukan para alumni program pelatihan pembuatan hantaran? dan Bagaimanakah dampak penguasaan keterampilan pembuatan hantaran terhadap kehidupan keluarganya? Penelitian ini dilakukan terhadap penyelenggaraan pelatihan pembuatan hantaran program PNPM Desa yang diselenggarakan pada Januari 2015 di Desa Cigugur Girang Kec. Parongpong Kab. Bandung Barat. Hasil penelitian ini akan diterbilkan dan dipublikasikan pada jurnal empowerment prodi PLS STKIP Siliwangi Bandung. Adapun kajian teori yang akan dipakai sebagai pisau analisa dalam penelitian ini adalah berhubungan dengan teori-teori pelatihan, efektivitas pelatihan, dan dampak dari pelatihan. Sementara metode penelitian akan mempergunakan metode kualitatif yang akan melihat dan mencermati pelatihan pembuatan hantaran di Desa Cigugur Girang Kec. Parongpong Kab. Bandung Barat Populasi yang akan dijadikan objek penelitian berjumlah 15 orang, dan pengambilan sampel dilakukan dengan mempergunakan Non Probability Sampling, Sampling Jenuh. Kesimpulan penelitian menunjukkan bahwa Pelatihan Keterampilan Hantaran bagi Kaum Perempuan di Desa Cugugur Girang Kec. Parongpong Kab. Bandung Barat dilakukan sebagaimana pelatihan pada umumnya. Setelah pelatihan para alumni mengembangkan ketempilannya dengan melakukan usaha penerimaan jasa pembuatan hantaran, dan mempunyai dampak terhadap peningkatan kehidupan keluarganya.
\end{abstract}

Kata Kunci: Keterampilan Hantaran, Kaum Perempuan

\begin{abstract}
The global crisis that hit the world economy peoples' frustrations resulting difficulties that exist throughout the country. The world crisis impact on the concerns that struck the Indonesian nation, where there is economic crisis since mid 1997 has been prolonged, with unemployment and growing poverty. This is evidenced by the absorption of labor in the economy there, and there are still many children who drop out of school (dropped out), as well as produktitif age children who are unable to continue their education to a higher level. As one of the efforts to overcome this crisis is to create a community of skilled through training to prepare them for entry into the labor market and to strive independently. The trainings are often held for people who need a stock of knowledge, skills, life skills, and attitudes to develop themselves, to develop the profession, work, independent business, and/or continuing education
\end{abstract}


kejenjang higher. One of the business services sector with the potential to grow is the manufacture of delivery. This research attempts to explain the problems with regard to the formulation of the description, the question What is the organization of training on making delivery? How did the implementation of a training program alumni manufacture of delivery? What is the impact and mastery of the skills of making delivery to family life? This research was conducted on the manufacture of conducting training events Village PNPM program held in January 2015 in the village of Cigugur Girang district. Parongpong Kab. West Bandung. Results of this study will be published in the journal diterbilkan and empowerment Prodi PLS STKIP Siliwangi Bandung. The study of theories that will be used as an analytic tool in this study is related to the theories of training, training effectiveness, and impact of the training. While the methods of the study will use qualitative methods that will see and watch-making training in the village conducting Cigugur Girang district. Parongpong Kab. West Bandung population that will be the object of study of 15 people, and the sampling is done by using Non Probability Sampling, Sampling Saturated. Conclusion The study shows that the conductivity Skills Training for Women in Rural Cugugur Girang district. Parongpong Kab. West Bandung done as training in general. After training the alumni develop by doing business receipts ketempilannya manufacturing services delivery, and have an impact on the increase in family life.

Keywords: Skills Delivery, Women

\section{A. PENDAHULUAN}

\section{Latar Belakang}

Sebagai salah satu upaya guna menanggulangi krisis masyarakat harus memiliki keterampilan, melalui pelatihan ini persiapan mereka masuk ke pasar kerja serta untuk berusaha secara mandiri. Dengan digulirkannya program-program pemerintah dibidang Pendidikan Non Formal (PNF) yang semakin hari semakin dipacu untuk tumbuh dan berkembang dengan mengadakan pelatihan-pelatihan di berbagai bidang keterampilan sebagai usaha Pemerintah untuk membuka seluas-luasnya kesempatan belajar bagi masyarakat yang kurang beruntung yang tidak dapat melanjutkan ke jenjang sekolah lebih tinggi / anak-anak dropped-out (putus sekolah).

\section{Rumusan Masalah}

a. Bagaimanakah penyelenggaraan pelatihan keterampilan hantaran di Desa Cigugur Girang Kec. Parongpong Kab. Bandung Barat?

b. Bagaimanakah implementasi hasil dari pelatihan keterampilan hantaran yang dilakukan alumni program PNPM Desa di Desa Cigugur Girang Kec. Parongpong Kab. Bandung Barat?

c. Bagaimanakah dampak penguasaan keterampilan pembuatan hantaran terhadap kehidupan keluarga alumni program PNPM Desa di Desa Cigugur Girang Kec. Parongpong Kab. Bandung Barat?

\section{B. KAJIAN TEORI DAN METODE}

Metode penelitian ini dalam pengkajiannya akan mempergunakan metode kualitatif. Hal ini berdasar pertimbangan atas kedalaman hasil penelitian yang berhubungan makna dari pada generalisasi, sehingga kekuatan penelitian akan peneliti maksimalkan dalam hal observasi dan wawancara, baik berkenaan dengan relevansi isi pertanyaan dengan kajian, maupun berhubungan dengan ketepatan terhadap respondennya. Teknik pengumpulan data dalam penelitian ini akan mempergunakan tiga teknik pengumpulan data yang populer dalam penelitian kualitatif, yaitu observasi, wawancara dan studi dokumentasi, dengan penjelasan dan pertimbangan sebagai berikut:

a. Observasi

b. Wawancara

c. Studi Dokumentasi

Setelah pengumpulan data maka dilakukan analisis data denan menggunakan metode deskripsi kualitatif secara mendalam.

\section{HASIL DAN PEMBAHASAN}

Secara keseluruhan warga belajar Pelatihan Keterampilan Hantaran telah menyelesaikan pelatihan dengan tuntas, sesuai dengan jangka waktu yang telah ditetapkan, yakni selama tiga hari atau 12 jam dan dilaksanakan empat jam setiap harinya. Pelatihan dilaksanakan jam $08.00-12.00$ WIB, pada tanggal 23 - 25 Januari 2015 bertempat di Gedung Yayasan SAE Cipta Mandiri Kec. Parongpong KBB 
Data tersebut menunjukan seluruh warga belajar yang mengikuti Pelatihan Keterampilan Hantaran bagi Kaum Perempuan tersebut lulus semua dengan predikat seluruhnya sangat memuaskan. Dengan begitu warga belajar telah memperoleh pengetahuan dan keterampilan hantaran serta memiliki sikap kemandirian dan kewirausahaan dengan baik.

\section{KESIMPULAN}

1. penyelenggaraan pelatihan keterampilan hantaran di Desa Cigugur Girang Kec. Parongpong Kab. Bandung Barat berhasil meningkatkan keterampilan peserta pelatihan

2. keterampilan dan wawasan Peserta Pelatihan Hantaran menjadi lebih bermutu, sehingga order yang didapatkan lebih memadai

3. Pelatihan keterampilan kecakapan hidup hantaran di PNPM Desa Cigugur Girang menghasilkan dampak positif untuk tumbuh dan berkembangnya usaha-usaha yang dijalankan oleh perempuan didaerahnya.

4. Penyelenggara PNPM Desa Cigugur Girang sebagai masukan pengembangan program keterampilan kearah yang lebih baik dan bermanfaat.

5. Para instruktur ataupun narasumber hendaklah melakukan persiapan yang totalitas untuk dapat menyajikan materi secara sempurna sehingga hasil yang didapatkan oleh para peserta pelatihan dapat maksimal.

6. Para alumni setelah memperoleh pengetahuan, wawasan, motivasi dan keterampialan dari pelatihan yang diselenggarakan PNPM Desa Cigugur Girang tidak berhenti untuk terus mengimplementasikan yang diperolehnya

7. Masyarakat hendaklah mengetahui dan memahami bahwa berbagai kegiatan pelatihan keterampilan, seperti halnya keterampilan hantaran mempunyai nilai manfaat yang sangat besar, yang dapat dijadikan salah satu solusi untuk pemecahan masalah yang ada dimasyarakat terutama dibidang peningkatan penghasilan dan krisis ekonomi, terbukti diantara banyak para alumni pelatihan yang merasa sangat beruntung dapat memperoleh pengetahuan dan keterampilan yang layak dengan profesi perempuan, sehingga dirasakan berhasil mengangkat harkat martabat dirinya dan menambah penghasilannya.

\section{E. DAFTAR PUSTAKA}

Arikunto. S, (2006), Dasar-Dasar Evaluasi Pendidikan. Jakarta: Bumi Aksara (2008), Dasar-Dasar Evaluasi Pendidikan (Edisi Revisi), PT Bumi Aksara, Jakarta

Arikunto S, dan Rekan, (2007). Evaluasi Program Pendidikan Pedoman Teoritis Praktis bagi Praktisi Pendidikan, PT Bumi Aksara, Jakarta.

Depdiknas RI, (2005), Kamus Besar Bahasa Indonesia, Balai Pustaka, Jakarta(2003), Undang-Undang RI No. 20 Tahun 3003 tentang Sistem Pendidikan Nasional, Jakarta 2003), Modul Diklat Management of Trainers, Pusdiklat Pegawai Depdiknas, Sawangan Depok.

Gita Setra, (2007), Himbauan dari dan untuk Lapangan, Jurnal BP-PLSP Regional II Jaya Giri.

Hasan, Engking Soewarman, (2003), Pengelolaan Program Pendidikan Luar Sekolah, Untuk Tugas penyusunan Makalah, SPs, UPI, Bandung (2007), Strategi Menciptakan Manusia yang Bersumber Daya Unggul, Jurusan PLS, FIP, UPI, Bandung.

Safuri Musa, (2005), Evaluasi Program. Pembelajaran dan Pemberdayaan Masyarakat. Yayasan Pengkajian Pendidikan Non Formal Indonesia Y-PIN Indonesia. (2006), Evaluasi Program PLS, Untuk Pendidikan Nonformal dan Pengembangan Sumber daya Manusia, PT Remaja Rosdakarya, Bandung. (2007), Sistem dan Manajemen Pelatihan Teori dan Aplikasi, Falah Production, Bandung.

Trisnamansyah, Sutaryat, (2008), Metode Penelitian Handout Perkuliahan Program Studi Pendidikan Luar Sekolah Program S-2 SPS-UPI, Bandung. 